\title{
Niche separation by littoral-benthic Chydoridae (Cladocera, Crustacea) in a deep lake - potential drivers of their distribution and role in littoral-pelagic coupling
}

\author{
Małgorzata ADAMCZUK* \\ Department of Hydrobiology, University of Life Sciences, B. Dobrzańskiego 37, 20-262 Lublin, Poland \\ *Corresponding author: malgorzata.adamczuk@up.lublin.pl
}

\begin{abstract}
Niche separation of 22 species of benthic Chydoridae was examined in a depth gradient in the littoral zone of a deep Lake Piaseczno (eastern Poland), by using a trap sampler. Individual species showed high segregation across the littoral zone according to depth, macrophyte biomass, total organic carbon (TOC), conductivity and pH, of which the depth turned out to be the most important. The species Acroperus harpae, Alona affinis, Alonella nana, Leydigia acanthocercoides, Pseudochydorus globosus, Pleuroxus trigonellus and Pleuroxus aduncus were found in the whole littoral zone, but the remaining Chydoridae species displayed clear spatial distribution, e.g. Coronatella rectangula, Acroperus elongatus, Alona guttata, Alonella excisa, Alonella exigua, Rhychotalona falcata, Monospilus dispar and Pleuroxus truncatus settled the shallower parts of the littoral, whereas Eurycercus lamellatus, Camptocercus rectirostris, Pleuroxus laevis, Graptoleberis testudinaria, Alona costata, Pleuroxus uncinatus and Alona intermedia were found mainly in areas located 3-6 $\mathrm{m}$ deep. To find out the role of Chydoridae in littoral-pelagic food web coupling, the contribution of chydorids to total number of Cladocera in the guts of fish was estimated showing that they are an important intervening link in nutrient movement from the littoral to the pelagic zone, as their contribution to the total cladoceran number found in guts of fish caught in the pelagic zone was even as high as $98 \%$. This study provides more insight into the nature of constraints associated with littoral-benthic cladocerans' habitat preferences and their importance in littoral-pelagic coupling.
\end{abstract}

Key words: chydorids, spatial distribution, habitat, macrophytes, depth.

Received: October 2013. Accepted: April 2014.

\section{INTRODUCTION}

Cladocera constitute an important part of the freshwater microfauna living in all types of waters. Among the cladocerans inhabiting lakes there are limnetic species which live in open water as well as littoral-benthic species. In some lakes (i.e., shallow ones) without a typical pelagic zone, both groups coexist spatially. In lakes with clearly distinguished pelagic and littoral zones, limnetic and littoral-benthic species show characteristic spatial distribution. Limnetic species exist in the whole of a lake, but their density is much higher in the pelagic zone, and their occurrence in the littoral zone differs seasonally and corresponds to developmental stage (Adamczuk and Mieczan, 2013) and environmental variables (Adamczuk, 2012). The occurrence of littoral-benthic cladocerans is restricted mainly to the littoral zone. Littoral-benthic cladocerans comprise plant-associated (inhabiting the surface of aquatic plants) and bottom-associated (living in the bottom sediment) species (Goulden, 1971), and these are represented mainly by the Chydoridae family.

Many organisms have been reported to display spatial distribution in water ecosystems, and vegetation is regarded to have an important influence on shaping the structural environment for invertebrates in many systems (McAbendroth et al., 2005; Mieczan 2010). Macrophytes diversify the space of a littoral zone, as the type and abundance of macrophyte vegetation change from nearshore to offshore along with an increasing depth, and they form distinct habitats (Havens, 1991). Macrophytes have a substantial effect on chydorids, including the formation of refuges or permanent habitats (Pennak, 1973; Cyr and Downing, 1988). Some chydorids are facultative filter feeders (Fryer, 1968), however, epiphyton growing on vegetation surfaces constitutes important food sources for those species that are mainly scrapers. Macrophytes affect the abiotic factors, including oxygen, temperature and $\mathrm{pH}$ (Jeppesen et al., 1998), and the specific spatial distribution of Chydoridae can result from their tolerance of changing physicochemical conditions. The role of environmental parameters in the distribution of Chydoridae still remains an unsolved problem. The same species usually inhabit a wide range of lakes, although in different abundances, and the major environmental requirements for many species are almost the same (Korhola, 1999), thus suggesting that they are ecologically flexible. On the other hand, it has been shown in some studies that Chydoridae are sensitive to 
many physical, chemical and ecological factors (de Eyto et al., 2002, 2003).

Chydoridae play some role in the littoral (benthic) food web (Williams, 1983) for being foraged by fish they may constitute an important nutrient flux into the pelagic food web. However, although some Chydoridae species have been suspected of constituting a valuable energetic resource for fish (Beklioglu and Jeppesen, 1999), the role of Chydoridae in the diet of fish as being links between benthic and pelagic food webs in lakes (Vander Zanden and Vadeboncoeur, 2002) has not yet been considered profoundly. On the other hand, some littoral habitats (e.g., thick patches of macrophytes) can interfere mechanically and visually when foraging fish seek prey (Gotceitas and Colgan 1989; Persson, 1993; Manatunge and Asaeda, 1999), and thus interfere littoral-pelagic coupling. Determining the distribution of littoral-benthic Chydoridae as well as the factors that influence their distribution and their role in the diet of fish can contribute to a better understanding the coupling of littoral-pelagic food web.

The present paper focuses on the horizontal distribution of Chydoridae, the role of environmental variables in their distribution, and their role in littoral-pelagic coupling. The goal of the study was to determine: i) what spatial distribution across the littoral zone do specific Chydoridae species display; ii) what the role of environmental variables in their spatial distribution is; and iii) what the role of Chydoridae in littoral-pelagic coupling is. The general hypotheses were: i) littoral benthic Chydoridae are not distributed chaotically and randomly, i.e., distinct species show specific spatial distribution; ii) some environmental variables, with macrophytes as the most important variable, determine the distribution of Chydoridae; and iii) Chydoridae constitute an important food source for fish; thus they display an important role as an intervening link of the movement of nutrients from the littoral-bottom substrate into the pelagic zone, but their accessibility to fish is interfered by the spatial complexity of the littoral habitats.

\section{METHODS}

The study was conducted in the littoral zone of mesotrophic Lake Piaseczno ( $51^{\circ} 23^{\prime} 03^{\prime \prime} \mathrm{N}, 23^{\circ} 01^{\prime} 46^{\prime}$ " E) which is situated in the eastern part of Poland. The lake's probable origin is limestone dissolution influencing morphometry, which is characterised by an almost circular sink and a great depth. The lake area is 83.2 ha and its maximum depth reaches $38.8 \mathrm{~m}$. The lake displays a low-trophic status. The concentration of total nitrogen amounts to $0.3 \mathrm{mg} \mathrm{L}^{-1}$, whereas the concentration of total phosphorus does not exceed $0.1 \mathrm{mg} \mathrm{L}^{-1}$. The average pri-

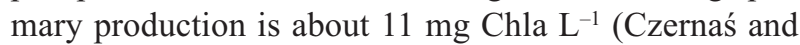
Serafin, 2007) and Secchi disc visibility ranges from between $4.5 \mathrm{~m}$ in summer to 6.5 in autumn. The littoral zone reaches a depth of 5-6 m due to high water transparency.

Samples were collected in two transects that were similar in depth and vegetation structure but were different in their distance from the shore to the deepest part of the lake. The transects were placed in the eastern (transect 1) and north-western (transect 2) part of the lake. Densities of Chydoridae were monitored monthly from April to November. Samples were collected just about noon using a 5-L trap sampler with a mechanism locking the trap after a fine tug. Macrophytes have been hypothesized as the most important factor in the distribution of Chydoridae, thus sampling sites were scheduled along with the gradient of macrophyte patches, namely: I, dominant macrophyte species: common reed Phragmites australis (Cav) Trin. ex Steud (depth $0.7 \mathrm{~m}$ ); II, macrophyte-free region with a sandy bottom (depth $1.5 \mathrm{~m}$ ); III, water milfoil Myriophyllum alterniflorum DC (depth $3 \mathrm{~m}$ ); IV, rigid hornwort Ceratophyllum demersum $\mathrm{L}$ in transect1, macroalgae Nitella flexilis in transect 2 (depth $4 \mathrm{~m}$ ); V, macroalgae Nitella flexilis (L) C. Agardh in transect 1, and $N$. flexilis and Chara fragilis Desv. in transect 2 (depth 5m); VI, sublittoral with the bottom grown with separate clusters of moss Drepanocladus sp. (depth 6.5 m) (Fig. 1). Whenever possible the samples were taken vertically at every $1-2 \mathrm{~m}$ of depth in every sampling point, both above and among the plants. Double samples were collected at each sampling site. A total of 38 samples was collected in each transect every month, and altogether 608 samples were collected for the whole field work period. Each sample, $10 \mathrm{~L}$ in volume, was sieved in a $40 \mu \mathrm{m}$ mesh net and preserved in formalin treated with glycerin to prevent deformation of the preserved organisms. In the laboratory the chydorids were classified to species level and counted (ind $\mathrm{m}^{-3}$ ) under a microscope at 100x magnification with the use of a Sedgewick-Rafter counting cell. Simultaneously with the Chydoridae sampling temperature, conductivity, $\mathrm{N}-\mathrm{NH}_{4}$ and $\mathrm{N}-\mathrm{NO}_{3}$ concentrations, $\mathrm{pH}$, concentration of dissolved oxygen, total organic carbon (TOC), and total suspended solids (TSS) were determined. The temperature, conductivity and $\mathrm{pH}$ were determined in situ with a multiparametric probe; TOC and TSS were determined using a PASTEL UV spectrophotometer, and $\mathrm{N}-\mathrm{NH}_{4}$ and $\mathrm{N}-\mathrm{NO}_{3}$ were analysed in the laboratory (Golterman, 1969). These data were used in further processes to estimate the impact of the physical and chemical factors on the distribution of Chydoridae species. Investigations of the macrophytes were carried out in April, May, June, August and October. The biomass of the common reed stands was estimated at 5 randomly chosen sites in an area of $0.25 \mathrm{~m}^{2}$ that was limited by a floristic fork. Species composition and biomass of submerged macrophytes were obtained with the use of a fork type of sampler consisting of two jaws of $0.16 \mathrm{~m}^{2}$ sampling area in 
the fully open position. These data were used in the further process of estimating the impact of macrophyte biomass on the distribution of Chydoridae.

In order to analyse the role of Chydoridae in littoral and pelagic coupling, their contribution to the diet of fish was computed. For that purpose fish were collected by gillnets in the pelagic zone. Netting was carried out in May, July and October. 5 fish species were selected to analyses, namely catfish Ictalurus nebulosus Lesueur, 1819, bleak Alburnus alburnus L., roach Rutilus rutilus L., perch Perca fluviatilis L., and European whitefish Coregonus albula L., for they constituted $96 \%$ of total number and $80.8 \%$ of total biomass of fish caught in Lake Piaseczno. The fish were killed with Propiscin and transported to the laboratory where their guts content was analysed. Cladocerans found in the fish guts were estimated to species level and counted. The percentage contribution of chydorids to total density of cladocerans as well as contribution of distinct species to the total density of Chydoridae were estimated.

One-way ANOVA was applied to test the statistical significance of differences in spatial variability of environmental factors. Tukey's multiple range test $($ at $\mathrm{P}<0.05$ ) was used to compare means when significant differences were found. Detrended correspondence analysis (DCA) was used to measure and illustrate the variability gradient indicated by the Chydoridae. Because the length of the gradient was $>2$, canonical correspondence analysis (CCA) was used to determine the variables that best predicted the distribution of Chydoridae. The set of environmental variables was reduced to a few orthogonal axes as composite environmental gradients structuring species distribution patterns. Stepwise forward selection was used to include significant variables $(\mathrm{P}<0.05)$ in the model. Automatic forward selection of environmental variables and the Monte Carlo permutation test (999 permutations) was used to determine the most important variables (Lepš and Šmilauer, 2003). Interactions between environmental variables and densities of Chydoridae were also calculated as Pearson's correlations. The proportion of variance explained by the environmental variables was quantified using variance partitioning. The ordination analyses were

a
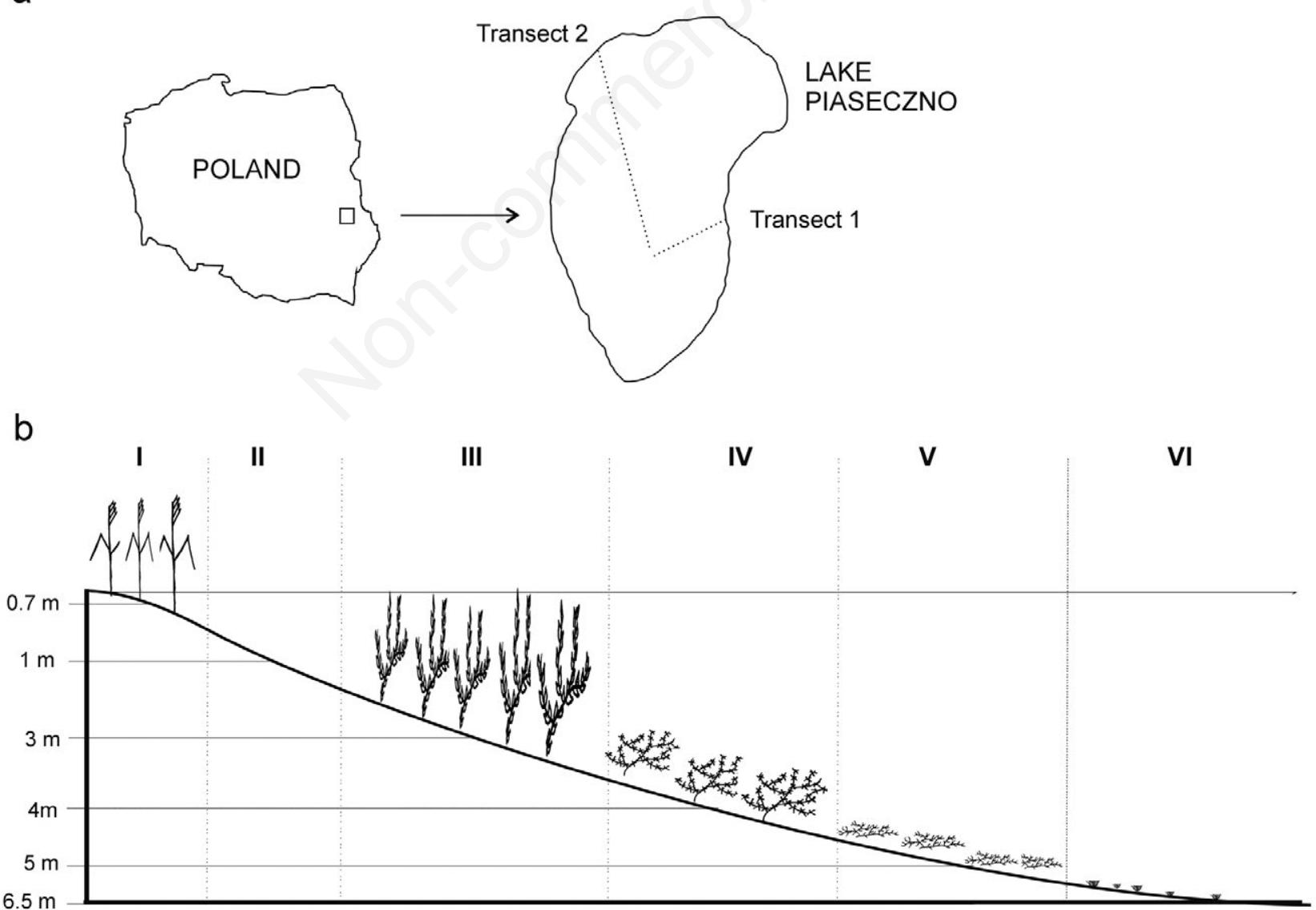

Fig. 1. Location of the study area (a) and sampling sites (b). 
performed by means of CANOCO 4.5 for Windows. The Bonferroni correction was not applied when multiple tests on different response variables (species) addressed the same hypothesis (Moran, 2003). Data were $\log (x+1)$ or arcsin transformed to improve normality before ANOVA and Pearson's correlations. Absolute abundances of Chydoridae were used for DCA and CCA analyses and data were not transformed.

\section{RESULTS}

\section{Environmental conditions}

During the study period the water temperature ranged from between 4.2 and $26.5^{\circ} \mathrm{C}$. The dissolved oxygen achieved $5.3-13.1 \mathrm{mg} \cdot \mathrm{dm}^{-3}$ and changed significantly in the horizontal gradient (ANOVA, $\mathrm{F}=14.0, \mathrm{P}=0.012$ ). The $\mathrm{pH}$ level remained between 6.17 and 8.55 (ANOVA, $\mathrm{P}>0.05)$. The conductivity $\left(82.3-143 \mu \mathrm{S} \mathrm{cm} \mathrm{cm}^{-2}\right)$ showed significant horizontal differences $(\mathrm{F}=56, \mathrm{P}=0.047)$. The total suspended solids (TSS) reached $4.9 \pm 5.3 \mathrm{mg} \mathrm{L}^{-1}$, the total organic carbon (TOC) had values of $2.5 \pm 7.9 \mathrm{mg} \mathrm{L}^{-}$ 1 , and both parameters differed horizontally $(\mathrm{F}=8.3$, $\mathrm{P}=0.03$ for TSS, $\mathrm{F}=5.5, \mathrm{P}=0.012$ for TOC). The $\mathrm{N}^{-\mathrm{NH}_{4}}$ achieved $0.121 \pm 0.087 \mathrm{mg} \mathrm{L}^{-1}(\mathrm{P}>0.05)$, whereas the $\mathrm{N}$ $\mathrm{NO}_{3}$ reached $0.113 \pm 0.126 \mathrm{mg} \mathrm{L}^{-1}(\mathrm{P}>0.05)$. The biomass of common reed and water milfoil showed statistically significant differences between the two transects. Common reed achieved $143.7 \pm 41.1 \mathrm{~g} \mathrm{~m}^{-2}$ in transect 1 and $387.5 \pm 62.9 \mathrm{~g} \mathrm{~m}^{-2}$ in transect $2(\mathrm{~F}=39.43, \mathrm{P}=0.031)$. The biomass of water milfoil was $102.6 \pm 51.2 \mathrm{~g} \mathrm{~m}^{-2}$ in transect 1 and $51.9 \pm 37.1 \mathrm{~g} \mathrm{~m}^{-2}$ in transect $2(\mathrm{~F}=81.2, \mathrm{P}=0.005)$. Macroalgae achieved a biomass of $17.7 \pm 5.3 \mathrm{~g} \mathrm{~m}^{-2}$ $(\mathrm{P}>0.05)$.

\section{Species number and density of Chydoridae: general results}

A total of 22 species of Chydoridae were found in the littoral zone of Lake Piaseczno. The highest number of species was found in sites I (13 species) and III (18 species). In most of sites the greatest species number was found in June, except for site I where the number of species escalated in July. Among the Chydoridae family the most abundant were A. harpae $\left(3828\right.$ ind $\left.\mathrm{m}^{-3}\right)$, A. exigua $\left(775\right.$ ind $\left.^{-3}\right)$, A. elongatus (522 ind $\mathrm{m}^{-3}$ ) and A. nana $\left(508\right.$ ind $\left.^{-3}\right)$. Species with a density ranging between 200 and 500 ind $\mathrm{m}^{-3}$ were $A$. affinis, G. testudinaria, E. lamellatus, $A$. excisa, and $C$. rectirostris. The density of $P$. aduncus, P. laevis, P. globosus and M. dispar ranged between 100-200 ind $\mathrm{m}^{-3}$. The density of the rest of the Chydoridae was lower than 100 ind $\mathrm{m}^{-3}$. A. harpae, which constituted $44 \%$ of all found Chydoridae individuals, was the most abundant in May and its monthly densities were much higher than the densities of the other chydorids. The densities of A. costata, A. excisa, A. exigua, A. guttata, $G$. testudinaria, $P$. aduncus, $P$. truncatus, and R. falcata reached their peaks in August-September. A. elongatus, A. affinis, A. intermedia, A. nana, C. rectirostris, C. rectangula, E. lamellatus, L. acanthocercoides, M. dispar, $P$. laevis, P. trigonellus, P. uncinatus, and P. globosus peaked between May and July.

\section{Chydoridae versus environmental variables}

In the CCA analysis, depth $\left(\lambda_{a}=0.065, F=2.93\right.$, $\mathrm{P}=0.014)$, macrophyte biomass $\left(\lambda_{\mathrm{a}}=0.055, F=2.77\right.$, $\mathrm{P}=0.026)$, conductivity $\left(\lambda_{\mathrm{a}}=0.051, F=2.53, \mathrm{P}=0.029\right)$, TOC $\left(\lambda_{\mathrm{a}}=0.043, F=2.13, \mathrm{P}=0.031\right)$ and $\mathrm{pH}$ level $\left(\lambda_{\mathrm{a}}=0.022, F=1.93, \mathrm{P}=0.043\right)$ were identified as the variables that best explained the distribution patterns of Chydoridae. CCA was performed using only these variables as all the other variables, including $\mathrm{N}^{-\mathrm{NH}_{4}}\left(\boldsymbol{\lambda}_{\mathrm{a}}=0.022\right), \mathrm{N}$ $\mathrm{NO}_{3}\left(\lambda_{\mathrm{a}}=0.017\right)$, temperature $\left(\lambda_{\mathrm{a}}=0.006\right)$, dissolved oxygen $\left(\lambda_{\mathrm{a}}=0.006\right)$, and TSS $\left(\lambda_{\mathrm{a}}=0.006\right)$ were non-significant $(\mathrm{P}>0.05)$. Ordination scores indicated a negative association between depth and the density of $P$. truncatus, $A$. elongatus, and $M$. dispar $(r=-0.61--0.29, \mathrm{P}=0.0017$ 0.042 ); whereas $A$. intermedia and $P$. uncinatus showed positive associations with depth $(r=0.026-0.31, \mathrm{P}=0.039$ 0.042) (Fig. 2). Thus, if to analyse the distribution of distinct species with respect to the main direction determined by CCA analysis, $P$. truncatus did not overstep the area of depth at $0.7 \mathrm{~m}$. A. elongatus and M. dispar occurred to a depth of $1.5 \mathrm{~m}$. A. excisa and $R$. falcata occurred exclusively up to $3 \mathrm{~m}$, whereas $A$. exigua and $A$. guttata up to a maximum depth of $5 \mathrm{~m}$. C. rectangula and L. acanthocercoides were also not found in areas deeper than $5 \mathrm{~m}$. E. lamellatus, C. rectirostris, G. testudinaria and P. laevis existed in regions located between $3 \mathrm{~m}$ and $7 \mathrm{~m}$ deep. $A$. intermedia and $P$. uncinatus were found between $5 \mathrm{~m}$ and $7 \mathrm{~m}$ deep, whereas $A$. costata was exclusively found in an area of a maximum depth of $3 \mathrm{~m}$. A. harpae, A. affinis, $A$. nana, $P$. globosus, $P$. trigonellus and $P$. aduncus were generally found in the whole littoral zone (Tab. 1).

The next factor that was determined in the CCA analysis as being important in Chydoridae distribution was macrophyte biomass. Ordination scores indicated a negative association between macrophyte biomass and the density of C. rectangula, P. truncatus, A. elongatus, and M. dispar $(r=-0.41--0.012, \mathrm{P}=0.017-0.021)$, and a positive association between that variable and the density of P. globosus, G. testudinaria, A. guttata, A. harpae, A. exigua, and $C$. rectirostris $(r=0.18-0.40, \mathrm{P}=0.022-0.031)$. When taking into consideration the distribution of Chydoridae along with the gradient of macrophyte biomass completed with raw data analysis, it seems that in most of the months the highest accumulation of chydorids was observed in beds of water milfoil, and the lowest in macrophyte-free littoral. Only in April and July did they gather in the highest densities in patches of common reed, 
and in October in beds of rigid hornwort. Their lowest density was observed in April and November in every habitat, but their density also diminished in July and/or August, except for the common reed, where their number in water escalated in July (Fig. 3). Although the highest agglomeration of Chydoridae was found in patches of water milfoil, particular chydorids displayed high densities in specific habitats, e.g. C. rectangula and P. truncatus occurred mainly among common reed; $A$. excisa and $P$. uncinatus were found mainly among common reed and water milfoil; whereas A. elongatus, $M$. dispar and $R$. falcata occurred mostly among reed and in the adjacent macrophyte-free littoral. The bulk of A. nana, P. globosus, G. testudinaria, A. costata and $A$. guttata were found in patches of water milfoil. Most of A. harpae, A. exigua and C. rectirostris were found in patches of water milfoil and rigid hornwort. E. lamellatus shifted in very similar densities in water milfoil, rigid hornwort, macroalgae and the sublittoral. L. acanthocercoides was mainly found in beds of water milfoil and macroalgae, and A. affinis occurred in

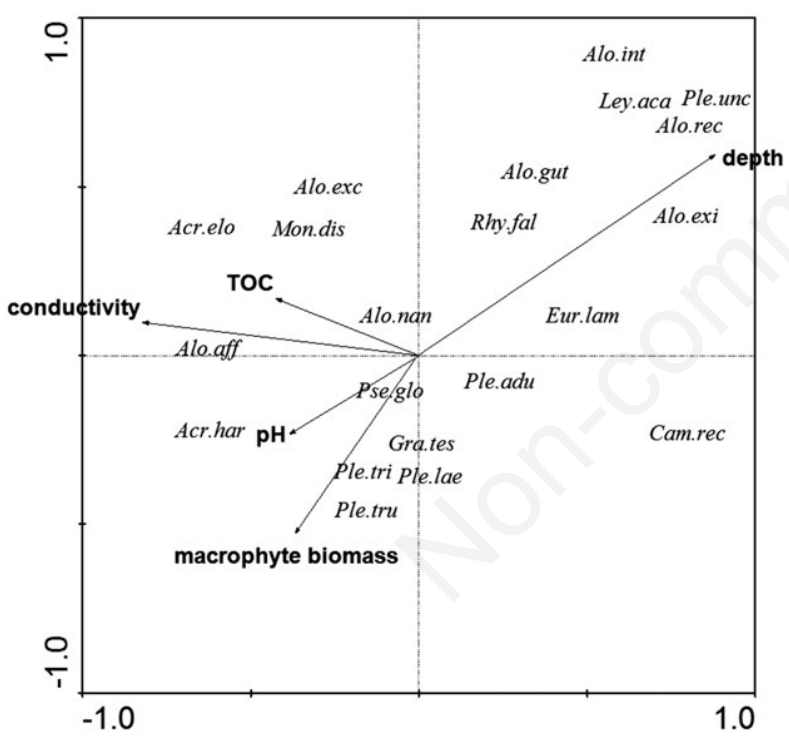

Fig. 2. Canonical correspondence analysis (CCA) biplot for Chydoridae assemblages showing species and environmental variables. Species codes: Alon.aff-Alona affinis, Alon.cos-Alona costata, Alon.gut-Alona guttata, Alon.int-Alona intermedia, Coro.rec-Coronatella rectangula, Alon.exc-Alonella excisa, Alon.exi-Alonella exigua, Alon.nan-Alonella nana, Acro.eloAcroperus elongatus, Acro.har-Acroperus harpae, Camp.rectCamptocercus rectirostris, Eury.lam-Eurycercus lamellatus, Grap.tes-Graptoleberis testudinaria, Leyd.aca-Leydigia acanthocercoides, Mono.dis-Monospilus dispar, Pleu.adu-Pleuroxus aduncus, Pseu.glo-Pseudochydorus globosus, Pleu.lae-Pleuroxul laevis, Pleu.tri-Pleuroxus trigonellus, Pleu.tru-Pleuroxus truncatus, Pleu.unc-Pleuroxus uncinatus, Rhyn.fal-Rhynchotalona falcata. water milfoil patches and in the sublittoral. P. laevis was found among rigid hornwort and macroalgae, whereas $P$. trigonellus settled the sublittoral. P. uncinatus and A. intermedia occurred mainly in the sublittoral (Fig. 4). Other environmental variables determined by CCA were conductivity, TOC and $\mathrm{pH}$. Conductivity was related to the densities of $C$. rectangula, A. elongatus, $L$. acanthocercoides, and $P$. aduncus $(\mathrm{r}=0.27-0.43, \mathrm{P}=0.012-0.48)$; TOC was related to $A$. exigua, $M$. dispar, $C$. rectirostris, $P$. aduncus and $P$. globosus $(\mathrm{r}=0.21-0.39, \mathrm{P}=0.029-0.042)$; whereas $\mathrm{pH}$ was related to the density of $A$. harpae $(\mathrm{r}=0.27, \mathrm{P}=0.021)$. The inertia in the species was 1.798 . Of this, the first axis explained $21 \%$ of the total variance, and the second axis $17.2 \%$. The canonical eigenvalues accounted together for $43.7 \%$.

\section{The role of Chydoridae in fish diet}

The contribution of Chydoridae species to the total number of cladocerans found in fish guts ranged from $3.2 \%$ for white fish to $98.2 \%$ for catfish. A total of 17 species of Chydoridae were found in the guts of fish. $C$. rectirostris and $A$. affinis were exclusively found in the guts of white fish, and these constituted, respectively, $47.3 \%$ and $52.7 \%$ of the total chydorid number. A total of 3 Chydoridae species were found in the diet of bleak, of which A. harpae was dominant (95.5\%). A total of 10 Chydoridae species were found in the diet of roach, and the most abundant species was $A$. harpae (82.5\%). E. lamellatus was most numerously found in the guts of perch $(84.63 \%)$; it co-occurred with 7 other species of Chydoridae. A total of 10 chydorids were found in the diet of catfish, the most numerous of which was E. lamellatus (95.57\%) (Tab. 2).

\section{DISCUSSION}

\section{Spatial distribution of Chydoridae}

In this study the hypothesis was that macrophytes strongly influence the distribution of Chydoridae because the spatial structure of macrophytes determines the quality of the habitats they create for chydorids. Some papers have indicated that plants with a dissected structure may represent better food sources for scrapers than morphologically simple plants due to the fact that their larger surface is colonised by epiphyton (Messyasz and Kuczyńska-Kippen, 2006; Zingel et al., 2006). Thus the number of chydorids per unit space could be expected to be higher in macrophyte thickets than in the littoral regions that were free from vegetation. Indeed, the abundances of free-swimming chydorids in the studied habitats were shaped as follows: water milfoil $>$ rigid hornwort $>$ common reed $>$ macroalgae $>$ sublittoral $>$ macrophytefree littoral. On the other hand, thick macrophytes may provide shelters for invertebrates that are potential pred- 
ators of plant-associated cladocerans (Johnson and Crowley, 1980; Johnson et al., 1985), and may cause a midsummer decline in density, which is often observed in populations of chydorids (van de Bond et al., 1995; Sakuma and Hanazato, 2002; Sakuma et al., 2004). The densities of Chydoridae in Lake Piaseczno, when consid- ered on average, changed according to the expected pattern, with large peaks in June and September and low levels, subsequently, during summer, especially for chydorids existing in beds of water milfoil and rigid hornwort. Curiously enough, chydorids living among common reed peaked only in July, when the density of Chydoridae

Tab. 1. Medians and $25 \%$ and $75 \%$ quartiles (in braces) of the proportional abundance ( $\%$ ) of chydorids relative to the total abundance in the entire study area.

\begin{tabular}{|c|c|c|c|c|c|}
\hline Lake depth & $0.7 \mathrm{~m}$ & $1.5 \mathrm{~m}$ & $3 \mathrm{~m}$ & $5 \mathrm{~m}$ & $6.5 \mathrm{~m}$ \\
\hline A. affinis (Leydig, 1860) & $\begin{array}{c}0.89 \\
(0-10.4)\end{array}$ & $\begin{array}{c}20.3 \\
(0.6-35.2)\end{array}$ & $\begin{array}{c}14.6 \\
(1.1-29.1)\end{array}$ & $\begin{array}{c}6.2 \\
(0-15.3)\end{array}$ & $\begin{array}{c}4.8 \\
(0-57.7)\end{array}$ \\
\hline A. costata Sars, 1862 & $\begin{array}{c}0 \\
(0-0)\end{array}$ & $\begin{array}{c}0 \\
(0-0)\end{array}$ & $\begin{array}{c}14.1 \\
(0-78.2)\end{array}$ & $\begin{array}{c}1.1 \\
(0-2.2)\end{array}$ & $\begin{array}{c}0 \\
(0-0)\end{array}$ \\
\hline A. exigua (Lilljeborg, 1853) & $\begin{array}{c}0.2 \\
(0-0.76)\end{array}$ & $\begin{array}{c}0 \\
(0-0)\end{array}$ & $\begin{array}{c}30.9 \\
(3.7-58.6)\end{array}$ & $\begin{array}{c}0 \\
(0-1.2)\end{array}$ & $\begin{array}{c}0 \\
(0-2.7)\end{array}$ \\
\hline A. excisa (Fisher, 1854) & $\begin{array}{c}11.5 \\
(0.6-55.8)\end{array}$ & $\begin{array}{c}0.2 \\
(0-3.5)\end{array}$ & $\begin{array}{c}41.3 \\
(0.43-85.1)\end{array}$ & $\begin{array}{c}0 \\
(0-0)\end{array}$ & $\begin{array}{c}0 \\
(0-0)\end{array}$ \\
\hline A. guttata Sars, 1862 & $\begin{array}{c}0 \\
(0-1.2)\end{array}$ & $\begin{array}{c}0 \\
(0-0)\end{array}$ & $\begin{array}{c}2.3 \\
(0-73.8)\end{array}$ & $\begin{array}{c}0 \\
(0-0)\end{array}$ & $\begin{array}{c}0 \\
(0-0)\end{array}$ \\
\hline A. elongatus (Sars, 1862) & $\begin{array}{c}58.3 \\
(13.9-91.1)\end{array}$ & $\begin{array}{c}8.9 \\
(0-41.7)\end{array}$ & $\begin{array}{c}0 \\
(0-0.2)\end{array}$ & $\begin{array}{c}0 \\
(0-0)\end{array}$ & $\begin{array}{c}0 \\
(0-0)\end{array}$ \\
\hline A. harpae (Baird, 1834) & $\begin{array}{c}19.3 \\
(8.4-37.8)\end{array}$ & $\begin{array}{c}5.1 \\
(2.5-8.5)\end{array}$ & $\begin{array}{c}36.4 \\
(13.2-47)\end{array}$ & $\begin{array}{c}4 \\
(0.8-25.3)\end{array}$ & $\begin{array}{c}0.57 \\
(0-1.5)\end{array}$ \\
\hline A. intermedia (Sars, 1862) & $\begin{array}{c}0 \\
(0-0)\end{array}$ & $\begin{array}{c}0 \\
(0-0)\end{array}$ & $\begin{array}{c}0 \\
(0-0)\end{array}$ & $\begin{array}{c}0 \\
(0-0)\end{array}$ & $\begin{array}{c}12 \\
(0-26.8)\end{array}$ \\
\hline A. nana (Baird, 1850) & $\begin{array}{c}3 \\
(0-9.5)\end{array}$ & $\begin{array}{c}1.4 \\
(0-7.9)\end{array}$ & $\begin{array}{c}17.8 \\
(0-55.6)\end{array}$ & $\begin{array}{c}10.5 \\
(3.6-28.6)\end{array}$ & $\begin{array}{c}7.9 \\
(1.2-28.4)\end{array}$ \\
\hline C. rectangula Sars, 1862 & $\begin{array}{c}13.1 \\
(0-28.3)\end{array}$ & $\begin{array}{c}0.4 \\
(0-2.9)\end{array}$ & $\begin{array}{c}5.3 \\
(0-33.3)\end{array}$ & $\begin{array}{c}0 \\
(0-0)\end{array}$ & $\begin{array}{c}0 \\
(0-0)\end{array}$ \\
\hline C. rectirostris Schoedler, 1862 & $\begin{array}{c}0 \\
(0-0)\end{array}$ & $\begin{array}{c}0 \\
(0-0)\end{array}$ & $\begin{array}{c}65.4 \\
(51.4-96.3)\end{array}$ & $\begin{array}{c}0 \\
(0-10.8)\end{array}$ & $\begin{array}{c}0 \\
(0-0.94)\end{array}$ \\
\hline E. lamellatus (O. F. Müller, 1783) & $\begin{array}{c}0 \\
(0-0)\end{array}$ & $\begin{array}{c}0 \\
(0-0)\end{array}$ & $\begin{array}{c}0.2 \\
(0-1.5)\end{array}$ & $\begin{array}{c}4.5 \\
(1-30.9)\end{array}$ & $\begin{array}{c}1.4 \\
(0-26)\end{array}$ \\
\hline G. testudinaria (Fisher, 1848) & $\begin{array}{c}0 \\
(0-0)\end{array}$ & $\begin{array}{c}0 \\
(0-0)\end{array}$ & $\begin{array}{l}0.05 \\
(0-3)\end{array}$ & $\begin{array}{c}0 \\
(0-0)\end{array}$ & $\begin{array}{c}0 \\
(0-0)\end{array}$ \\
\hline L. acanthocercoides (Fisher, 1854) & $\begin{array}{c}1.9 \\
(0-15.6)\end{array}$ & $\begin{array}{c}0 \\
(0-0)\end{array}$ & $\begin{array}{c}8.6 \\
(0-68.7)\end{array}$ & $\begin{array}{c}14.5 \\
(0-15.6)\end{array}$ & $\begin{array}{c}0 \\
0 \\
(0-0)\end{array}$ \\
\hline M. dispar Sars, 1862 & $\begin{array}{c}33.2 \\
(0-85.5)\end{array}$ & $\begin{array}{c}14.8 \\
(0-28.6)\end{array}$ & $\begin{array}{c}13 \\
(0-19.7)\end{array}$ & $\begin{array}{c}0 \\
(0-0)\end{array}$ & $\begin{array}{c}0.47 \\
(0-2.1)\end{array}$ \\
\hline P. aduncus (Jurine, 1820) & $\begin{array}{c}7.5 \\
(0-59.7)\end{array}$ & $\begin{array}{c}8.5 \\
(0-16.7)\end{array}$ & $\begin{array}{c}24.4 \\
(0-47.9)\end{array}$ & $\begin{array}{c}7.1 \\
(0-18.5)\end{array}$ & $\begin{array}{c}0.37 \\
(0-3.1)\end{array}$ \\
\hline P. globosus (Baird, 1843) & $\begin{array}{c}0 \\
(0-0)\end{array}$ & $\begin{array}{c}0 \\
(0-0.9)\end{array}$ & $\begin{array}{c}87.1 \\
(30.5-94.6)\end{array}$ & $\begin{array}{c}0 \\
(0-0.9)\end{array}$ & $\begin{array}{c}0 \\
(0-8.3)\end{array}$ \\
\hline P. laevis Sars, 1862 & $\begin{array}{c}0 \\
(0-0)\end{array}$ & $\begin{array}{c}0 \\
(0-0)\end{array}$ & $\begin{array}{c}0.5 \\
(0-33.3)\end{array}$ & $\begin{array}{c}0 \\
(0-38.9)\end{array}$ & $\begin{array}{c}0 \\
(0-0)\end{array}$ \\
\hline P. trigonellus (O. F. Müller, 1785) & $\begin{array}{c}0.69 \\
(0-1.9)\end{array}$ & $\begin{array}{c}0 \\
(0-0)\end{array}$ & $\begin{array}{c}6.6 \\
(0-1.4)\end{array}$ & $\begin{array}{c}1.4 \\
(0-58.3)\end{array}$ & $\begin{array}{c}11.8 \\
(0-16.7)\end{array}$ \\
\hline P. truncatus (O. F. Müller, 1785) & $\begin{array}{c}0.3 \\
(0-50)\end{array}$ & $\begin{array}{c}0 \\
(0-0)\end{array}$ & $\begin{array}{c}0 \\
(0-0)\end{array}$ & $\begin{array}{c}0 \\
(0-0)\end{array}$ & $\begin{array}{c}0 \\
(0-0)\end{array}$ \\
\hline P. uncinatus Baird, 1850 & $\begin{array}{c}0 \\
(0-0)\end{array}$ & $\begin{array}{c}0 \\
(0-0)\end{array}$ & $\begin{array}{c}0 \\
(0-0)\end{array}$ & $\begin{array}{c}2 \\
(0-19)\end{array}$ & $\begin{array}{c}3 \\
(0-33.3)\end{array}$ \\
\hline R. falcata (Sars, 1862) & $\begin{array}{c}10.7 \\
(0-78.5)\end{array}$ & $\begin{array}{c}14.3 \\
(0-28.6)\end{array}$ & $\begin{array}{c}12.5 \\
(0-29.2)\end{array}$ & $\begin{array}{c}0 \\
(0-0)\end{array}$ & $\begin{array}{c}0 \\
(0-0)\end{array}$ \\
\hline
\end{tabular}


decreased in the rest of the habitats. Chydorids displayed a low density in macroalgae patches, as only $8 \%$ of them occurred there. There is no evidence as to connections between macroalgae and littoral-benthic cladocerans, but a low density of planktonic animals among macroalgae is a known phenomenon. Macroalgae may support weak food conditions because they release allelopathic substances (Anthoni et al., 1980, Wium-Andersen et al., 1982) that inhibit the growth of epiphyton (Blindow, 1987). They also suppress phosphorus resuspension from the bottom sediments, which creates a limitation for phytoplankton development (van den Berg et al., 1994; Blindow et al., 2002). It cannot be excluded that littoralbenthic Chydoridae avoided macroalgae in Lake Piaseczno because the low density of the chydorids coincided with an absence of species preferring that habitat. A few Chydoridae species clearly avoided areas covered with submerged macrophytes, including $C$. rectangula and $P$. truncatus, which occurred mainly among common reed, and A. elongatus, $M$. dispar and $R$. falcata, which occurred mostly in common reed patches and in the adjacent macrophyte-free littoral. Their habitat preferences are probably related to their ways of life, as these species are known to rest on mineral benthic substrates and collect their food by using scrapers whilst scrambling along firm surfaces (Fryer, 1968).

\section{Chydoridae versus environmental variables}

Association of depth with the first axis in the CCA ordination suggests that this variable was the most important in the spatial distribution of Chydoridae. In general, Chydoridae can be split into three groups: i) species found in the whole littoral zone (A. harpae, A. affinis, A. nana, $P$. globosus, $P$. trigonellus, $P$. aduncus); ii) species settling shallower parts of the littoral (C. rectangula, A. elongatus, A. guttata, A. excisa, A. exigua, $R$. falcata, M. dispar, $P$. truncatus); and iii) species found mainly in areas located 3-6 m deep (E. lamellatus, C. rectirostris, P. laevis, G. testudinaria, $A$. costata, $P$. uncinatus, $A$. intermedia). Some studies have reported that lake depth influences the community structure of many cladocerans (Korhola et al., 2000; Amsinck et al., 2006), and even in morphologically homogeneous lakes Chydoridae can display patterns of separation along the depth level which are forced upon them by the thermal properties, UV exposure, food resources and predators associated with these varying depths (Nevalainen, 2012).

Other variables that had strong predictable effects on the Chydoridae community structure in Lake Piaseczno were TOC, $\mathrm{pH}$ and conductivity. Littoral-benthic Chydoridae are mainly scrapers grazing on epiphytic algae, but some of them can effectively filter phytoplankton (Beklioglu and Jeppesen, 1999). In this study the distribution of A. exigua, C. rectirostris, P. aduncus and P. globosus was related to the TOC concentration. TOC values provide information about utilising and non-utilising fractions of carbon amount in an organic compound. Thus, although that variable cannot influence the chydorids directly, high correlations between the TOC concentration and elevated densities of some Chydoridae suggest that these species could prefer areas of higher productivity and/or they can also utilise organic matter suspended in the water. The distribution of $A$. harpae was related to the $\mathrm{pH}$ level, and $\mathrm{pH}$ was found to be an important factor in the distribution of Chydoridae in a geographical scale (de

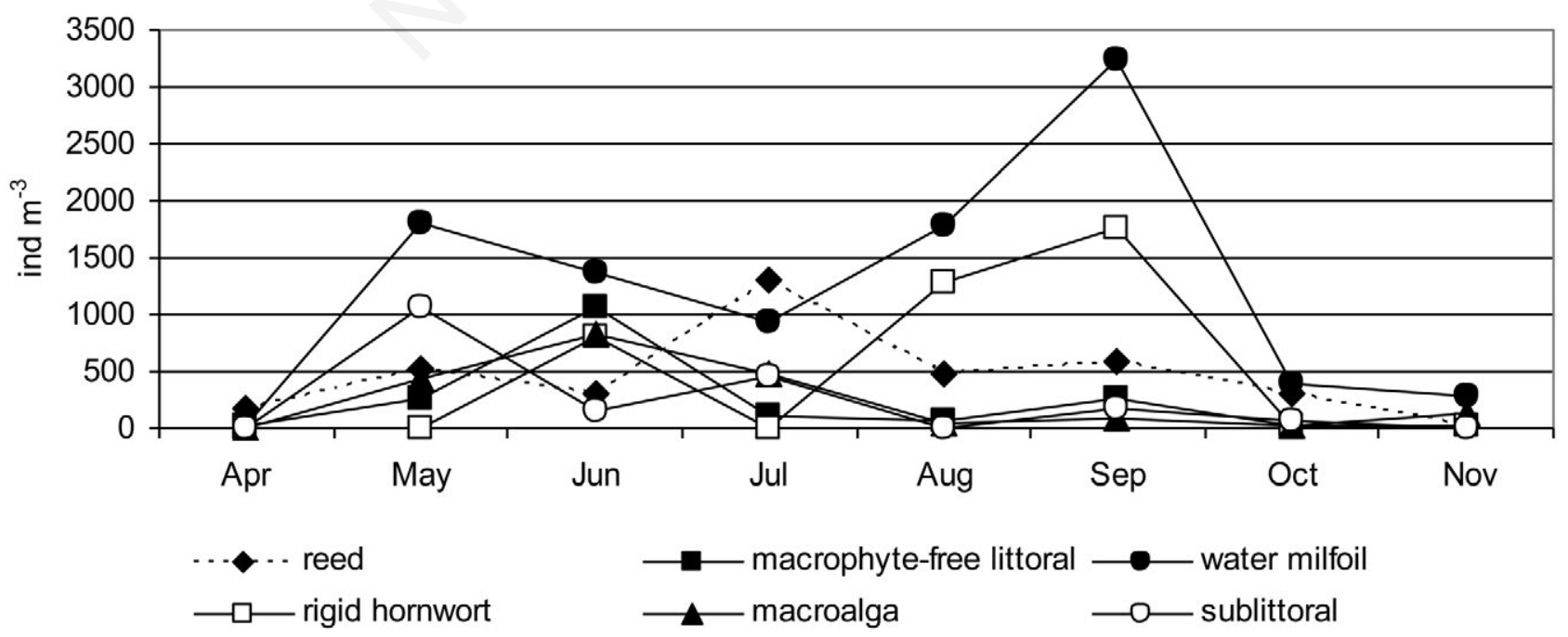

Fig. 3. Seasonal changes in the density of Chydoridae in distinct habitats of the littoral zone of Lake Piaseczno. 

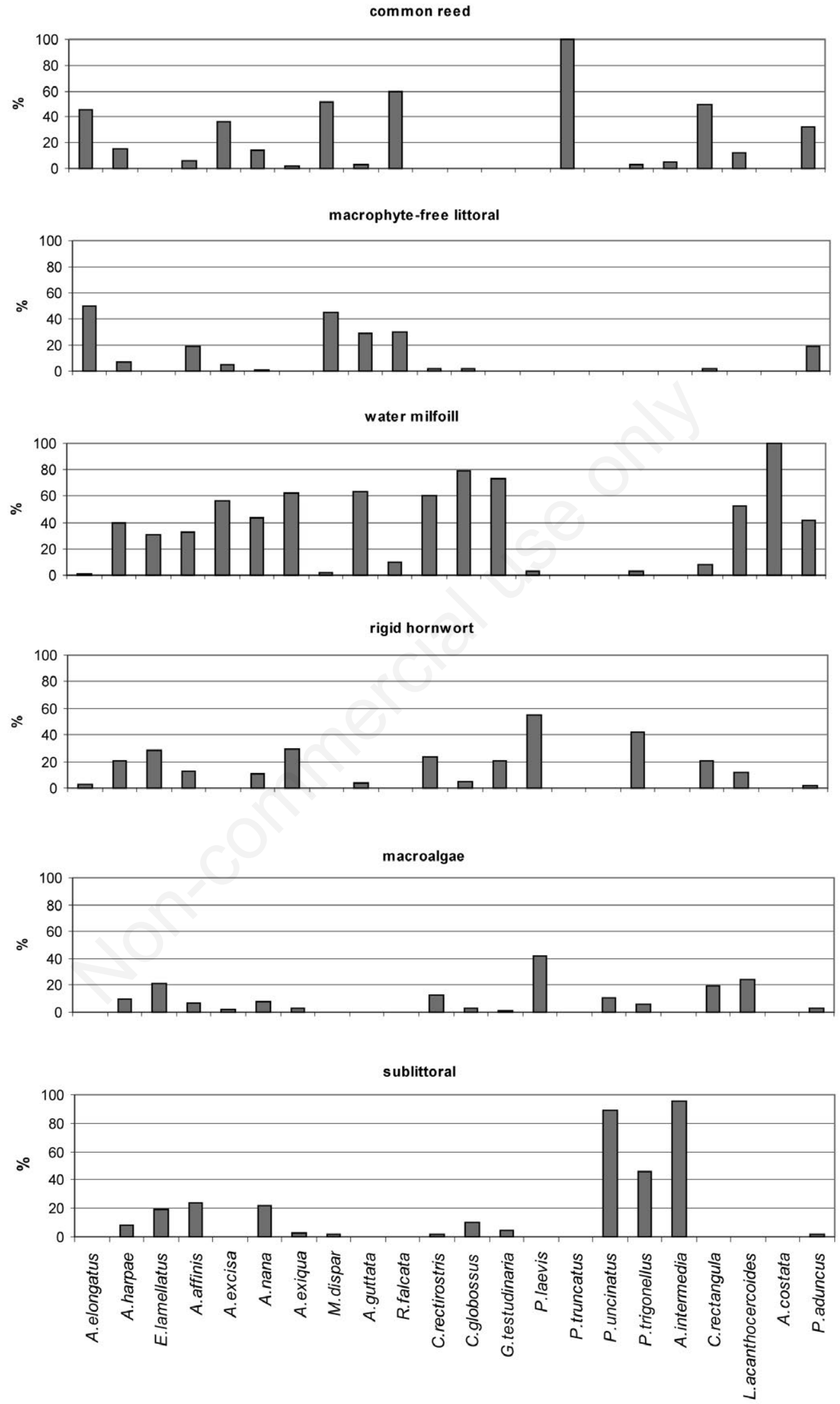

Fig. 4. Densities of Chydoridae species in distinct habitats of the littoral zone of Lake Piaseczno. 
Eyto et al., 2003). Walseng et al. (2008) revealed that habitat type is of lesser importance to community composition in comparison to $\mathrm{pH}$. However, in some studies the effect of $\mathrm{pH}$ appeared to be insignificant (Nilssen and Sandøy, 1986, 1990). In a lake-scale, changes in water pH are related to photosynthesis and respiration. Regarding that $A$. harpae was present in the whole littoral zone and its distribution was not restricted mainly to macrophytecovered areas where intense photosynthesis takes place, high densities of $A$. harpae in areas of elevated $\mathrm{pH}$ suggest that the species could select areas of intense phytoplankton development. A relatively large group of species selected habitats according to conductivity values. Some papers have reported a significant (negative or positive) effect of conductivity of planktonic cladocerans (Green et al., 2005; Adamczuk, 2012), and the present study shows that this factor significantly influenced the distribution of some littoral-benthic species. Nevalainen (2012) found segregation of some chydorids in relation to temperature, but in Lake Piaseczno temperature turned out to be an unimportant factor.

\section{Species co-occurrence}

Some species, by showing very elevated densities in particular habitats and total absence in the others, displayed distribution thresholds that were difficult to ex- plain by changing physicochemical conditions alone. Species that were weakly influenced by environmental factors but showed clear spatial separation were $A$. affinis, A. costata, A. intermedia, A. nana, P. laevis, P. trigonellus, $P$. uncinatus, and $R$. falcata. Some species, namely $A$. costata, A. intermedia, and P. truncatus, were found in one or two habitats only. As a result, Chydoridae created specific assemblages of species in a spatial scale. According to Makarewicz and Likens (1975), species do not cooccur randomly because the spatiotemporal crossing of species results from competitive interactions. Descriptions of competitive interactions among cladocerans have been limited primarily to pelagic species (Kerfoot et al., 1985; DeMott and Kerfoot, 1982; Vanni, 1986). Competitive interactions among Chydoridae have not been reported yet; however, the distribution thresholds of chydorids found in Lake Piaseczno suggest that interspecific competition may play some role in their populations. Chydoridae display a wide range of body sizes, and according to a classical view of competition as summarised in the size-efficiency hypothesis (Brooks and Dodson, 1965), large species are more competitive than small-bodied species. This hypothesis was modified by many authors, including Bengtsson (1987), Tessier and Woodruff (2002), and Semenchenko et al. (2007), thus proving that competitive abilities in cladocerans do not depend exclusively on species size. Likewise, this study on Chydoridae does

Tab. 2. Percentage structure of Chydoridae in guts of fish in Lake Piaseczno.

\begin{tabular}{|c|c|c|c|c|c|}
\hline & White fish (\%) & Bleak (\%) & Perch $(\%)$ & Roach (\%) & Catfish (\%) \\
\hline A. elongatus & 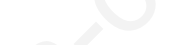 & & & & 0.02 \\
\hline A. harpae & & 95.5 & 82.4 & 16.6 & 2.3 \\
\hline A. affinis & 52.7 & 2.3 & 8 & 0.2 & 0.3 \\
\hline A. costata & & & & 0.1 & \\
\hline A. excisa & & & 1.3 & & \\
\hline A. nana & & & & & 0.1 \\
\hline C.rectirostris & 47.3 & & 0.9 & 0.9 & 1.4 \\
\hline C. rectangula & & & 0.2 & & \\
\hline E. lamellaus & & 2.2 & 5.6 & 81.5 & 95.4 \\
\hline G. testudinaria & & & & 0.1 & 0.2 \\
\hline M. dispar & & & & & 0.1 \\
\hline L. acanthocercoides & & & 0.9 & & \\
\hline P. aduncus & & & 0.2 & & \\
\hline P. laevis & & & 0.2 & 0.1 & 0.02 \\
\hline P. trigonellus & & & & & 0.1 \\
\hline P. uncinatus & & & 0.2 & 0.1 & \\
\hline P. globosus & & & & 0.3 & \\
\hline
\end{tabular}


not support Brooks' and Dodson hypothesis, for the dominant species along the littoral zone gradient was the intermediate body-sized species $A$. harpae that was co-dominated by similarly sized $A$. elongatus in patches of common reed and the adjacent macrophyte-free littoral, small-sized A. exigua in patches of water milfoil and rigid hornwort, and large-sized E. lamellatus in patches of macroalgae and in the sublittoral.

\section{The role of Chydoridae in littoral-pelagic coupling}

Pelagic and littoral food webs do not function independently but can converge by the movement of fish and planktonic invertebrates that forage in both littoral and pelagic zone (Schindler and Scheuerell, 2002). For years the role of typical planktonic cladocerans in the diet of the so-called planktivorous fish has been researched, whereas the role of benthic cladocerans, including Chydoridae, was underestimated. Instead, the present study showed that the contribution of benthic cladocerans to the diet of fish reached above $90 \%$ of cladocerans consumed. The positioning of fish along the littoral-pelagic gradient varied among species. White fish and bleak had the lowest contribution to transfer energy from the littoral to pelagic food web, and perch and catfish had the highest. No coincidences between density of Chydoridae in the environment and their contributions to the fish diet were found, because although willingly consumed A. harpae constituted $44 \%$ of Chydoridae in the studied lake, other species that were dominant in the diet of the fish constituted less than 5\% of the total number of chydorids in Lake Piaseczno.

A comparison between the spatial distribution of chydorids and their presence in fish guts can provide us with a picture of the availability of littoral resources for fish. In general, predators may consume less prey when the structural elements associated with complex habitats affects the ability of predators (Holbrook and Schmitt, 1988). Thus, the hypothesis was made that the presence of macrophyte patches restricts exploration of the littoral zone by fish. Nevertheless, the comparison of Chydoridae distribution in littoral habitats and their presence in fish guts gave only rough concept of littoral resources availability for distinct fish species, suggesting that roach, bleak and catfish could forage in the whole pelagic zone, whereas white fish and perch probably explored only deeper parts of the littoral zone. Concurrently, the hypothesis that spatial complexity of the littoral zone interferes with the availability of benthic resources to fish remains unproved.

\section{CONCLUSIONS}

The study provided quantitative support that Chydoridae species display a distribution threshold at one time in one lake. Although chydorids are suspected of being eco- logically flexible and tolerant to environmental gradients, individual species showed high segregation across the littoral zone according to depth, macrophyte biomass, TOC, conductivity and $\mathrm{pH}$, of which depth turned out to be the most important factor. Although many species displayed spatial distribution along with an increasing macrophyte biomass, CCA ordination showed that the variable had a minor importance compared with depth, in the spatial distribution of Chydoridae. The contribution of littoral-benthic Chydoridae was above $90 \%$ of the total number of cladocerans in the guts of certain species of fish caught in the pelagic zone, thus suggesting that Chydoridae play an important but underestimated role in littoral-pelagic coupling.

\section{ACKNOWLEDGMENTS}

I thank the two anonymous reviewers; their constructive criticism helped greatly to improve the previous draft of the paper.

\section{REFERENCES}

Adamczuk M, 2012. Spatial distribution of juvenile and adult stages of limnetic Cladocera in relation to selected environmental factors. J. Limnol. 71:112-118.

Adamczuk M, Mieczan T, 2013. Spatial distribution of broodbearing females of limnetic species of Cladocera. Cr. Biol. 336:457-465.

Amsinck SL, Strzelczak A, Bjerring R, Landkildehus F, Lauridsen TL, Christoffersen K, Jeppesen E, 2006. Lake depth rather than planktivory determines cladoceran community structure in Faroese lakes - evidence from contemporary data and sediments. Freshwater Biol. 51:2124-2142.

Anthoni U, Christophersen C, Øgård Madsen J, Wium-Andersen S, Jakobsen N, 1980. Biologically active sulphur compounds from the green alga Chara globularis. Phytochemistry 19:1228-1229.

Beklioglu M, Jepesen E, 1999. Behavioural response of plantassociated Eurycercus lamellatus (Ö. F. Müller) to different food resources and fish cues. Aquat. Ecol. 33:167-173.

Bengtsson J, 1987. Competitive dominance among Cladocera: are single-factor explanations enough? Hydrobiologia 145:245-257.

Blindow I, 1987. The composition and density of epiphyton on several species of submerged macrophytes - neutral substrate hypothesis tested. Aquat. Bot. 29:157-168.

Blindow I, Hargeby A, Andersson G, 2002. Seasonal changes of mechanisms maintaining clear water in a shallow lake with abundant Chara vegetation. Aquat. Bot. 72:315-334.

Brooks JL, Dodson SI, 1965. Predation, body size and composition of plankton. Science 150:28-35.

Cyr H, Downing JA, 1988. The abundance of phytophilous invertebrates on different species of submerged macrophytes. Freshwater Biol. 20:365-374.

Czernaś K, Serafin A, 2007. Changes in phytoplankton productivity in the pelagic zone of the mesotrophic Piaseczno lake in 1987-1989 and 2001-2003. Oceanol. Hydrobiol. Stud. 36 (suppl. 1):209-212. 
de Eyto E, Irvine K, Free G, 2002. The use of members of the family Chydoridae (Anomopoda, Branchiopoda) as an indicator of lake ecological quality in Ireland. Biol. Environ. 102B:81-91.

de Eyto E, Irvine K, Garcia-Criada F, Gyllström M, Jeppesen E, Kornijów R, Miracle RM, Nykänen M, Bareiss C, Cerbin S, Salujõe J, Franken R, Stephens D, Moss R, 2003. The distribution of chydorids (Branchiopoda, Anomopoda) in European shallow lakes and its application to ecological quality monitoring. Arch. Hydrobiol. 156:181-202.

DeMott WR, Kerfoot WC, 1982. Competition among cladocerans: nature of the interaction between Bosmina and Daphnia. Ecology. 63:1949-1966.

Dolson R, McCann K, Rooney N, Ridgway M, 2009. Lake morphometry predicts the degree of habitat coupling by a mobile predator. Oikos 118:1230-1238.

Fryer G,1968. Evolution and adaptative radiation in the Chydoridae (Crustacea:Cladocera): a study in comparative functional morphology and ecology. Philos. T. R. Soc. B. 254: 221-283.

Golterman HL, 1969. Methods for chemical analysis of freshwaters. Blackwell Scientific Publ.: 172 pp.

Gotceitas V, Colgan P, 1989. Predator foraging success and habitat complexity: quantitative test of the threshold hypothesis. Oecologia 80:158-166.

Goulden CE, 1971. Environmental control of the abundance and distribution of chydorid Cladocera. Limnol. Oceanogr. 16:320-331.

Green AJ, Fuentes C, Moreno-Ostos E, Rodrigues da Silva SL, 2005. Factors influencing cladocerans abundance and species richness in brackish lakes in Eastern Spain. Ann. Limnol. Int. J. Lim. 41:73-81.

Havens KE, 1991. Summer zooplankton dynamics in the limnetic and littoral zones of a humic acid lake. Hydrobiologia 215:21-29.

Holbrook SJ, Schmitt RJ, 1988. The combined effect of predation risk and food reward on patch selection. Ecology 69:125-134.

Jeppesen E, Søndergaard M, Kirsten C, 1998. The structuring role of submerged macrophytes in lakes. Springer, New York: 427 pp.

Johnson DM, Crowley PH, 1980. Odonate "hide and seek" habitat-specific rules, pp 567-579? In: WC Kerfoot (ed.), Evolution and ecology of zooplankton communities. Hannover (NH) University Press of New England.

Johnson DM, Crowley PH, Bohanan RE, Watson CN, Martin TH, 1985. Competition among larval dragonflies: a field enclosure experiment. Ecology 66:119-128.

Kerfoot WC, DeMott WR, DeAngelis DL, 1985. Interactions among cladocerans: food limitation and exploative competition. Arch. Hydrobiol. Beih. Ergeb. Limnol. 21:431-451.

Korhola A, 1999. Distribution pattrens of Cladocera in subarctic Fennoscandian lakes and their potential in environmental reconstruction. Ecography 22:357-373.

Korhola A, Olander H, Blom T, 2000. Cladoceran and chironomid assemblages as quantitative indicators of water depth in subarctic Fennoscandian lakes. J. Paleolimnol. 24:43-54.

Lepš J, Šmilauer P, 2003. Multivariate analysis of ecological data using CANOCO. University Press, Cambridge: 251 pp.
Makarewicz JC, Likens GE, 1975. Niche analysis of a zooplankton community. Science 190:1000-1003.

Manatunge J, Asaeda T, 1999. Optimal foraging as the criteria of prey selection by two centrarchid fishes. Hydrobiologia 391:223-240.

McAbendroth L, Ramsay PM, Foggo A, Rundle SD, Bilton DT, 2005. Does macrophyte fractal complexity drive invertebrate diversity, biomass and body size distribution? Oikos 111:279-290.

Messyasz B, Kuczyńska-Kippen N, 2006. Periphytic algal communities:a comparison of Typha angustifolia L. and Chara tomentosa L. beds in three shallow lakes (West Poland). P. J. Ecol. 54:15-27.

Mieczan T, 2010. The influence of emergent and submerged macrophyte beds on ciliate communities in a shallow lake. Oceanol. Hydrobiol. St. 30:107-115.

Moran MD, 2003. Arguments for rejecting the sequential Bonferroni in ecological studies. Oikos 100:403-405.

Nevalainen L, 2012. Distribution of benthic microcrustaceans along a water depth gradient in an Austrian Alpine lake Sedimentary evidence for niche separation. Limnologica 42:65-71.

Nilssen PJ, Sandøy S, 1986. Acidification history and crustacean remains:some ecological obstacles. Hydrobiologia 143:349-354.

Nilssen PJ, Sandøy S, 1990. Recent lake acidification and cladoceran dynamics:surface sediment and core analyses from lakes in Norway, Scotland and Sweden. Philos. T. R. Soc. B. 327:299-309.

Pennak RW, 1973. Some evidence for aquatic macrophytes as repellent for a limnetic species of Daphnia. Int. Revue Ges. Hydrobiol. 58:569-576.

Persson L, 1993. Predator-mediated competition in prey refuges: the importance of habitat dependent prey resources. Oikos 68:12-22.

Sakuma M, Hanazato T, 2002. Abundance of Chydoridae associated with plant surfaces, water column and bottom sediments in the macrophyte zone of a lake. Verh. Internat. Verein. Limnol. 28:975-979.

Sakuma M, Hanazato T, Saji A, Nakazato R, 2004. Migration from plant to plant: an important factor controlling densities of the epiphytic cladoceran Alona (Chydoridae, Anomopoda) on lake vegetation. Limnology 5:17-23.

Semenchenko VP, Razlutskij VI, Feniova IY, Aibulatov DN, 2007. Biotic relations affecting species structure in zooplankton communities. Hydrobiologia 579:219-231.

Schindler DE, Scheuerell MD, 2002. Habitat coupling in lake ecosystems. Oikos 98:177-189.

Tessier AJ, Woodruff P, 2002. Trading off the ability to exploit rich versus poor food quality. Ecol. Lett. 5:685-692.

van de Bond WJ, Davids C, Spaas SJH, 1995. Seasonal dynamics and spatial distribution of chydorid cladocerans in relation to chironomid larvae in the sandy littoral zone of an oligo-mesotrophic lake. Hydrobiologia 229:125-138.

van den Berg MS, Breukelaar AW, Breukers C, Coops H, Doef RW, Meijer ML, 1994. Vegetated areas with clear water in turbid shallow lakes. Aquat. Bot. 49:193-196.

Vander Zanden MJ, Vadeboncoeur Y, 2002. Fishes as integrators of benthic and pelagic food webs in lakes. Ecology $83: 2153-2161$. 
Vanni M, 1986. Competition in zooplankton communities: suppression of small species by Daphnia pulex. Limnol. Oceanogr. 31:1039-1056.

Walseng B. Yan ND, Pawson T, Skarpaas O, 2008. Acidity versus habitat structure as regulators of littoral microcrustacean assemblages. Freshwater Biol. 53:290-303.

Williams JB, 1983. A study of summer mortality factors for natural populations of Chydoridae (Cladocera). Hydrobiologia 107:131-139.
Wium-Andersen S, Anthoni U, Houen G, 1982. Allelopathic effects on phytoplankton by substances isolated from aquatic macrophytes (Charales). Oikos 39:187-190.

Zingel P, Nõges P, Tuvikene L, Feldmann T, Järvalt A, Tõnno I, Agasild H, Tammert H, Luup H, Salujõe J, Nõges T, 2006. Ecological processes in macrophyte- and phytoplankton dominated shallow lakes. Proc. Estonian Acad. Sci. Biol. Ecol. 55:280-307. 